\title{
Performance of starter broiler chickens fed diet supplemented with Smartchoice
} phytase enzyme

${ }^{1}$ Ekine, O. A. and ${ }^{2}$ Onunkwo, D. N. ${ }^{\prime}$ Department of Animal Science, University of Port Harcourt, Rivers State

${ }^{2}$ College of Animal Science and Animal Production, Michael Okpara University of Agriculture, Umudike, Abia State Corresponding author: donunkwo1@gmail.com; 08033388622

\section{Abstract}

Phytase is essential for enhancing nutritional value of feed and improving animal growth performance and health. A study was conducted to evaluate the influence of Smartchoice phytase enzyme supplementation in the diet of starter broiler chickens. A total of 150 Ross strain broiler chicks were used for the study and allotted to five treatment groups of 30 birds each. Each group was further divided into three replicates of 10 birds per replicate. Five isonitrogenous $(21.40 \% \mathrm{CP})$ and iso-caloric $(2975.40 \mathrm{kcal} / \mathrm{kg} \mathrm{ME})$ dietary treatments were compounded to contain $0 \mathrm{~g} / 100 \mathrm{~kg}\left(T_{1}\right), 10 \mathrm{~g} / 100 \mathrm{~kg}\left(T_{2}\right), 15 \mathrm{~g} / 100 \mathrm{~kg}\left(T_{3}\right), 20 \mathrm{~g} / 100 \mathrm{~kg}\left(T_{4}\right)$ and $25 \mathrm{~g} / 100 \mathrm{~kg}\left(T_{5}\right)$ of a commercial Smartchoice phytase enzyme preparation for 28 days in a Completely Randomized Design (CRD). Feed and water were provided to the chicks adlibitum. Daily feed intake and weekly body weight were measured. The result showed that the daily feed intake and daily protein intake were not affected $(P>0.05)$ by Smartchoice phytase enzyme supplementation. Final live weight, daily weight gain and total weight gain were significantly different among treatments. Protein efficiency ratio were significantly $(P<0.05)$ higher in $T_{1}$ (2.10) than $T_{5}(1.80)$ but similar to $T_{2}$ (2.05), $T_{3}$ (2.05) and $T_{4}$ (1.96). Feed conversion ratio was significantly $(P<0.05)$ different in $T 5$ (2.58) and $T_{1}(2.02)$ but similar $(P>0.05)$ in $T_{1}$ (2.02), $T_{2}(2.28), T_{3}(2.31)$ and $T_{4}$ (2.38). Mortality was lowest in T5. Total feed cost per bird and daily feed cost per bird were not affected $(P>0.05)$ by Smartchoice phytase enzyme supplementation while cost per $\mathrm{kg}$ of feed and daily feed cost per bird were not significantly $(P>0.05)$ affected. The findings from this study showed that Smartchoice phytase enzyme could be supplemented up to $20 \mathrm{~g}$ per $100 \mathrm{~kg}$ in the diet of starter broiler chickens.

Keywords: Smartchoice phytase, nutritional value, protein efficiency, feed cost

\section{Introduction}

Phytase inclusion in animal feed results in a lower excretion of the phosphorous content in manure, contributing to a lower environmental impact of livestock farming. Results from several studies have shown increased phosphorus digestibility and utilization; hence reduced phosphorous excretion into the environment due to phytase addition to poultry diets (Bedford, 1995). The nutritional and economic value of corn soybean meal and other ingredients commonly used in poultry diets can be improved by the addition of appropriate preparation of phytase, carbohydrate, and other enzyme additives. Phytase and cellulose are important enzymes used in commercial poultry production. Phytase is anti-nutritional factors present in most plant materials that irreversibly chelates divalent cations and interferes with amino acid absorption in the gastrointestinal tract of birds, as well as other monogastrics (Wisema, 1992). Moreover, the faecal excretion of phylate phosphorous and chelated minerals is a major source of soil and water pollution when wastes are applied to farmland. Dietary phytase supplementation is used to improve utilization of phosphorous and other ionically active nutrients like amino acids and minerals, ultimately reducing mineral 
emissions (Odetalla, 2000). Producers of poultry and other animals aim to provide high quality, homogenous products in a short time and at a minimal cost (Onunkwo, 2019). Therefore, any measure taken to reduce feed cost, improve efficiency of digestion and nutrient utilization, accelerate biochemical reactions and reduce cost of production especially for small scale farmers will be of immense benefit.

\section{Materials and method}

Location of study

The study was conducted at the Poultry Unit of the Teaching and Research Farm of the Michael Okpara University of Agriculture, Umudike, Abia State. Umudike is located on latitude $05^{\circ} \mathrm{C} 28^{\prime}$ North and $07^{\circ} \mathrm{C} 32^{\prime}$ East and lies at an altitude of $122 \mathrm{~m}$ above sea level. This area is situated within the tropical rainforest zone of West Africa which is characterized by long duration of rainfall (April October) and short period of dry season (November-March). Average rainfall is $2169.8 \mathrm{~mm}$ in $148-155$ rain days. Average ambient temperature is $26^{\circ} \mathrm{C}$ with a range $22^{\circ} \mathrm{C}$ and $30^{\circ} \mathrm{C}$. Its relative humidity ranges from 50 to $90 \%$ (NRCRI, 2019).

Experimental diet, animals and management

Five Iso-caloric (2975.40 kcal/kg ME) and Iso-nitrogenous $(21.40 \%$ crude protein) experimental diets supplemented with Smartchoice ${ }^{\circledR}$ phytase enzyme at inclusion levels of $0 \mathrm{~g}, 10 \mathrm{~g}, 15 \mathrm{~g}, 20 \mathrm{~g}$ and $25 \mathrm{~g}$ were formulated and compounded. The Smartchoice phytase enzyme was supplied by farm Associates Nig. Ltd. Enugu State. It was produced by Eggriculture Inc USA. The percentage compositions of the diets are presented in Table 1. A total of 150, one day old Ross strain broiler chicks were procured from a reputable hatchery. A week before the arrival of the chicks, the pens, feeders and drinkers were washed and disinfected with disinfectant. The chicks were weighed to get their initial live weight before introducing them into different treatments. The drinkers were cleaned twice daily (morning and evening) and other routine management practices were carried out.

Table 1 : Gross composition of starter broilers fed experimental diet supplemented with Smartchoice ${ }^{\circledR}$ phytase enzyme

\begin{tabular}{lccccc}
\hline & \multicolumn{3}{c}{ Treatment (Enzyme inclusion) } & & \\
Ingredients & $\mathrm{T} 1(0 \mathrm{~g} / 100 \mathrm{~kg})$ & $\mathrm{T} 2(10 \mathrm{~g} / 100 \mathrm{~kg})$ & $\mathrm{T} 3(15 \mathrm{~g} / 100 \mathrm{~kg})$ & $\mathrm{T} 4(25 \mathrm{~g} / 100 \mathrm{~kg})$ & $\mathrm{T} 5(25 \mathrm{~g} / 1 \mathrm{~kg})$ \\
\hline Maize & 55.00 & 55.00 & 55.00 & 55.00 & 55.00 \\
Fishmeal & 3.00 & 3.00 & 3.00 & 3.00 & 3.00 \\
Soybean & 32.00 & 32.00 & 32.00 & 32.00 & 32.00 \\
Bone meal & 2.00 & 2.00 & 2.00 & 2.00 & 2.00 \\
Palm kernel cake & 7.20 & 7.20 & 7.20 & 7.20 & 7.20 \\
Lysine (\%) & 0.20 & 0.20 & 0.20 & 0.20 & 0.20 \\
Methionine (\%) & 0.10 & 0.10 & 0.10 & 0.10 & 0.10 \\
*vitamin premix (\%) & 0.25 & 0.25 & 0.25 & 0.25 & 0.25 \\
Salt (\%) & 0.25 & 0.25 & 0.25 & 0.25 & 0.25 \\
TOTAL & $\mathbf{1 0 0}$ & $\mathbf{1 0 0}$ & $\mathbf{1 0 0}$ & $\mathbf{1 0 0}$ & $\mathbf{1 0 0}$ \\
Crude protein & 21.40 & 21.40 & 21.40 & 21.40 & 21.40 \\
Me kcal/kg & 2975.40 & 2975.40 & 2975.40 & 2975.40 & 2975.40
\end{tabular}

*Premix supplied package per kg starter diet; Vitamin A 15,000 IU, Vitamin D3, 13,000 I.U, Thiamine 2mg, Riboflavin 6mg, Pyridoxin 4mg, Cobalamine 0.05g, Biotin 0.08mg, Choline Chroride 0.05g, Maganise 0.096g, Zinc $0.06 \mathrm{~g}$, Iron $0.024 \mathrm{~g}$, Copper $0.06 \mathrm{~g}$, Iodine $0.014 \mathrm{~g}$, Selenium $0.024 \mathrm{mg}$, Cobalt 0.024 and Antioxidant $0.125 \mathrm{~g}$ Enzyme name: Smartchoice ${ }^{\circledR}$ Phytase Enzyme 


\section{Ekine and Onunkwo}

\section{Data collection and analysis}

The initial weights of the broilers were determined at the start of the experiment after one week of brooding. The broilers were weighed weekly per replicate in order to ascertain their average weight gain. Feed intake was measured daily. This was determined as difference between feed consumed and feed refusal. Weighing of the birds was between 8:00am and 12:00 noon weekly with the removal of feed before weighing. Data collected was subjected to Analysis of variance (ANOVA) as described by Steel and Torrie (1980). The means were separated using Duncan's New Multiple Range Test (Duncan, 1955). Other parameters were evaluated from the following formulae:

Total weight gain $=$ Final live weight (g/bird) - initial live weight (g/bird)

Average daily gain $(\mathrm{g} / \mathrm{bird})=$

Final live weight $(g /$ bird $)$-initial live weight $(g /$ bird $)$

No of days the experiment lasted (21)

Feed conversion ratio $=\underline{\text { Feed intake }}$

Protein Intake $\equiv$ Weight gain

$\%$ crude protein of diet X Quantity of feed consumed 100

Protein Efficiency Ratio = weight gain Protein intake

Total feed cost/bird = Total feed intake/bird $\mathrm{X}$ Cost $/ \mathrm{kg}$ feed

Daily feed cost $/$ bird =

Total feed cost/bird

No of days the experiment lasted (21)

Cost $/ \mathrm{kg}$ weight gain $=\mathrm{FCR} \mathrm{X} \operatorname{cost} / \mathrm{kg}$ of feed

\section{Results and discussion}

The proximate compositions of the experimental diets are shown in Table 2 . The dry matter (DM) contents of the diets ranges from $92.12 \%$ to $93.22 \%$. Diet 2 with $10 \mathrm{~g} / 100 \mathrm{~kg}$ of phytase enzyme had higher ether extract (EE) compared to the other diets. As the level of phytase supplementation increases, the crude fibre (CF) contents of the diet reduces.
Supplementation with phytase also caused the crude protein $(\mathrm{CP})$ content of the diets to drop from $23.54 \%$ in the control to $20.15 \%$ in diet 3. Diet 2 has the highest metabolizable energy (ME) of 368.93 calories/gramme while the least energy in the diet was obtained in the control. The ash contents of the diets reduced from $9.70 \%$ in diet 1 to $3.09 \%$ in diet 3 and increased in diet 4 and diet 5 respectively. The control diet had the least nitrogen free extract (NFE) while diet 3 had the highest value of NFE. The growth performance of starter broiler chickens fed diet supplemented with Smartchoice phytase enzyme at varying levels is presented in Table 3. The result shows that there was no significant $(\mathrm{P}>0.05)$ difference in the initial live weights, daily feed intake, total feed intake, and the daily protein intake of the chicks supplemented with the enzyme. The final live weight, daily weight gain, total weight gain and the protein efficiency ratio (PER) were significantly $(\mathrm{P}<0.05)$ higher in $\mathrm{T}_{1}$ than in $\mathrm{T}_{5}$ but similar $(\mathrm{P}>0.05)$ to $\mathrm{T}_{2}, \mathrm{~T}_{3}$ and $\mathrm{T}_{5}$. The feed conversion ratio (FCR) also showed significant difference between $T_{5}$ and $T_{1} . T_{5}$ had the highest value for FCR while $T_{1}$ had the lowest but similar value of FCR to $T_{2}, T_{3}$ and $\mathrm{T}_{4}$, Mortality was significantly $(\mathrm{P}<0.05)$ higher in $T_{3}$ and $T_{4}$ than in $T_{1}$ and $T_{2} . T_{5}$ recorded $0 \%$ mortality. This result indicates that the supplementation of broiler starter chickens with phytase enzyme above $20 \mathrm{~g}$ $/ 100 \mathrm{~kg}$ of feed produced a corresponding decrease in the performance of the starter broiler chickens. Saima et al. (2009) reported improved feed intake, total weight gain and better FCR in low phosphorous diets supplemented with phytase enzyme up to $750 \mathrm{IU} / \mathrm{kg}$ of feed compared to a diet without supplementation. Similar report was also given by Cabahug et al, (1999) and Shirley and Edwards (2003). The findings from this study may be due to the fact that the bioavailability of phosphorous in the control diet is sufficient in meeting the 
phosphorous needs of starter broiler chickens; hence little or no need for supplementation. Supplementary phytase would have produced a better result if the level of phosphorous in the starter broiler chicken diets were reduced below the optimal requirements. Bone meal as an animal source of phosphorous used in the formulation of the diets is considered to contain $100 \%$ bioavailability in phosphorous (Olomu, 1995).

Table 2: Proximate composition of experimental diets (\% dry matter)

\begin{tabular}{llllll}
\hline Parameters (\%) & T1 & T2 & T3 & T4 & T5 \\
\hline Dry matter & 92.62 & 93.22 & 92.12 & 92.71 & 92.67 \\
Crude protein & 23.54 & 20.46 & 20.15 & 20.44 & 20.63 \\
Crude fibre & 5.82 & 5.74 & 4.06 & 4.10 & 3.82 \\
Nitrogen free extract & 49.19 & 53.78 & 59.95 & 55.83 & 52.29 \\
Ether extract & 4.37 & 9.84 & 4.87 & 4.93 & 4.93 \\
Ash & 9.70 & 3.40 & 3.09 & 7.41 & 11.00 \\
\hline
\end{tabular}

Table 3: Growth performance characteristics of broiler chickens fed diet supplemented smartchoice phytase enzyme

\begin{tabular}{lllllll}
\hline Parameters & T1 & T2 & T3 & T4 & T5 & SEM \\
\hline IBW $(\mathrm{g} / \mathrm{b})$ & 50.73 & 50.50 & 50.57 & 50.87 & 50.55 & 0.05 \\
AFI $(\mathrm{g} / \mathrm{b})$ & 1757.00 & 1753.92 & 1763.16 & 1723.96 & 1718.36 & 1.30 \\
ADFI $(\mathrm{g} / \mathrm{b} / \mathrm{d})$ & 62.75 & 62.64 & 62.97 & 61.57 & 61.37 & 0.62 \\
FBW $(\mathrm{g} / \mathrm{b})$ & $726.00^{\mathrm{a}}$ & $700.33^{\mathrm{ab}}$ & $699.00^{\mathrm{ab}}$ & $671.00^{\mathrm{ab}}$ & $627.67^{\mathrm{b}}$ & 12.30 \\
AWG $(\mathrm{g} / \mathrm{b})$ & $675.27^{\mathrm{a}}$ & $649.50^{\mathrm{ab}}$ & $648.43^{\mathrm{ab}}$ & $620.13^{\mathrm{ab}}$ & $577.12^{\mathrm{b}}$ & 8.25 \\
ADWG $(\mathrm{g} / \mathrm{b} / \mathrm{d})$ & $24.11^{\mathrm{a}}$ & $23.19^{\mathrm{ab}}$ & $23.15^{\mathrm{ab}}$ & $22.14^{\mathrm{ab}}$ & $20.61^{\mathrm{b}}$ & 0.30 \\
FCR & $2.60^{\mathrm{b}}$ & $2.70^{\mathrm{ab}}$ & $2.72^{\mathrm{ab}}$ & $2.78^{\mathrm{ab}}$ & $2.98^{\mathrm{a}}$ & 0.50 \\
Mortality & $2.28^{\mathrm{b}}$ & $2.28^{\mathrm{b}}$ & $5.56^{\mathrm{a}}$ & $5.56^{\mathrm{a}}$ & $0.00^{\mathrm{c}}$ & 0.09 \\
\hline
\end{tabular}

a-b-c Means with different super scripts in the same row are significant different (pE0.05), S.E.M: Standard Error of mean. IBW=Initial Body Weight, FBW=Final Body Weight, AWG=Average Weight Gain,

ADWG=Average Daily Weight Gain, AFI=Average Feed Intake, ADFI=Average Daily Feed Intake, FCR=Feed Conversion Ratio.

The feed cost benefit of starter broiler chickens fed diet supplemented with Smartchoice phytase enzymes is shown in Table 4. The total feed intake, total feed cost per bird and daily feed cost per bird were statistically similar $(\mathrm{P}>0.05)$ among the treatment means. Cost $/ \mathrm{kg}$ of feed and cost $/ \mathrm{kg}$ weight gain varied statistically $(\mathrm{P}<0.05)$ among the treatments. $\mathrm{T}_{5}$ was statistically $(\mathrm{P}<0.05)$ higher than $\mathrm{T}_{1}$ and $\mathrm{T}_{2}$ but similar $(\mathrm{P}>0.05)$ to $\mathrm{T}_{3}$ and $\mathrm{T}_{4}$ in terms of cost $/ \mathrm{kg}$ of feed and cost $/ \mathrm{kg}$ weight gain. Increase in the level of phytase supplementation produced a corresponding increase in cost of feed and cost of weight gain. Saima et al (2009) reported a corresponding statistically similar $(\mathrm{P}>0.05)$ increase in the cost of feed as the level of supplementation of phytase enzyme increases. However, this transcends to a reduced cost $/ \mathrm{kg}$ of live weight.

Table 4: Feed cost benefit of starter broilers fed diet supplemented with Smartchoice phytase enzyme

\begin{tabular}{lllllll}
\hline Parameters & T1 & T2 & T3 & T4 & T4 & SEM \\
\hline Cost/kg feed (N) & $98.74^{\mathrm{b}}$ & $99.34^{\mathrm{b}}$ & $99.64^{\mathrm{ab}}$ & $99.94^{\mathrm{ab}}$ & $100.24^{\mathrm{a}}$ & 0.14 \\
Cost of feed consumed/B (N) & 129.08 & 129.44 & 130.53 & 128.85 & 128.41 & 1.26 \\
Cost/kg weight gain $(\mathrm{N})$ & $215.31^{\mathrm{b}}$ & $224.27^{\mathrm{b}}$ & $228.18^{\mathrm{ab}}$ & $235.34^{\mathrm{ab}}$ & $256.02^{\mathrm{a}}$ & 5.10 \\
\hline
\end{tabular}

${ }^{a b c}$ Means on the same row with different superscripts are significantly $(\mathrm{p}<0.05)$ different. 


\section{Ekine and Onunkwo}

Conclusion

The result of this study has indicated that the Smartchoice phytase enzyme could be supplemented up to $20 \mathrm{~g} / 100 \mathrm{~kg}$ in the diet of starter broiler chickens. However, since there were no significant differences in terms of the parameters evaluated when compared to the control diet, it becomes reasonable to re-evaluate the phosphorous level in the diets so that at the lower phosphorous level, the enzyme supplementation at higher inclusion level would produce better results.

\section{References}

Anon 1999. Fungal/phytase can improve the bio-availability of plant phosphorous. Nutria. Rev. 9:207208.

Apata, D. F. 1999. The utilization of ureaheat treated whole and dehulled jack beans by broiler chicks. Animal conference of Nigerian society for animal production, Ilorin, Kwara State, March 1999:261-262.

Apata, D. F. and Ojo, C. U. 2000. Efficiency of the Trichoderma vivid enzyme complex a broiler starter fed cowpea testa based diets. Proceedings $25^{\text {th }}$ Lupins for monogastric animals by means of exogenous enzymes. In : Proceedings of the EU LUPINE (FAIR 3ct 96-1995). Meeting, INRA, Paris France, 14-15 February.

Back-Knusen K. E. C. 2000. Digestibility of the lupin by monogastric and enzyme treatment improvement of the nutric value of white lupins for monogastric animals by means of exogenous enzymes. In: proceedings of EU LUPINE (FAIR 3ct 96-1995). Meeting, INRA, France 14-15 February.

Bedford, M. R. 1995. Mechanism of action and potential environmental benefits from the use of feed enzymes preparations on the nutritional value of cereals for poultry. A preview Journal of animal feed science. Pp. 4, 263285.

Bedford, M. R. and Schelze, H. 1998. Ezogenous enzymes for pigs and poultry Nutri. Res. Rev. 11:91-114.

Beudeker, R. F. 2000. Development and production of enzyme sources. In: proceedings of the XXI world's poult. Congress, Mortreal, Canada (www.wpc.2000.org)

Beudeker, R. F. and Pen. J. 1995. Development of plants seed expressing phytase as a feed additive. In: European Symp. On feed enzymes: Noor dwijkerhout. 225-235.

Cabahug, S., Ravindran, Y., Shelle, P.H. and Bryden, W. L. 1999. Response of broiler chicken to microbial phytase supplementation as influenced by dietary phytic acid and non phytate phosphorous contents. i. effect on the bird performance and toc ash. Bri. Poult. Sci. 40: 660-666.

Classen, H. L. and M. R. Bedford 1991. The use of enzymes to improve the nutritive value of poultry feeds. Pp. 98-116. In: recent advances on animal nutrition, ButterworthHeinemann, Ltd. Oxford.

Cowieson, A. J., Sarkilahtic, K. L., Apajalahti, J. H. A., acanovic, T. and Bedford, M.R. 2006a. Caecalmicroflora in broilers fed diets containing Camelina with or without enzyme supplementation. Proceedings of the XXI World's Poult. Congress, Mortreal, Canada, May 2000 (www.wpc.com and www.wpc2000.org)

Cowieson, A.J., Acanovic, T. and 
Performance of starter broiler chickens fed diet supplemented with Smartchoice phytase enzyme

Bedford, M. R. 2000b. enzyme supplementation of diets containing Camelinasativameal for poultry. Brit Poult. Sci. 41:689690.

Danicke, S., Simon, O. and Jerock, H. 1999. Effect of supplementary of xylase, or B-glucanase containing enzyme preparations to either ryeor basely-based boiler diets on performance and nutrients digestibility. Archive for Getflugelkunds 63:252-259.

Diericks, N. A. 1989. Biotechnology aids to improve feed digestion enzymes and fermentation arch. Ani. Nutria. 39:240-261.

Duncan, D. B. 1995. Multiple Range and multiple f-tests. A Biometric approach 1:1-42.

Encyclopedia America 1981. $10^{\text {th }}$ anniversary Ed. USA broiler Inc. p. 295.

Ensminger, M. E. 1991. Animals science digest, $1^{\text {st }} \mathrm{Ed}$. Interstate publishers, Inc printed in the United States of America.

Fairel, D. L. and Martin, E. A. 1998. Strategies to improve the nutritive value of rice bran in poultry diets. The addition of food enzymes and ducks gave no response. Brit. Poult. Sci. 39:549-554.

Ferraz de Olivera, M. I. 1998. Enzymes treated lupins spp. Seeds as an alternative source of protein for broilers. PhD Thesis, University of Aberdeen.

Fetuga, B. L. A. 1984. Energy, protein and amino acid requirements of chickens in Nigeria in: proceeding $1^{\text {st }}$ August School seminar, University of Ibadan.

Ferket, P. R. 1993. Practical use of feed enzymes for turkeys and broiler. J. Applied Poultry Science. 2:75-78.

Franson, J. C., Murray, H. C. and Bunck,
C. 1986. Enzyme activities in plasma, liver and muscle of five avian species. J. Wildisis. 21(1):3339.

Gibson, K. 1995. The poultry stability of animal feed enzymes in. $2^{\text {nd }}$ European Symp. On feed enzymes, Noordwijikerhout, 157-162.

Inborr, J. and Bedford, N. R. 1991. The influence of supplementary feed enzyme on nutrient disappearance of digesta characteristics in G.I.T. of early weaned pigs. Proc. $5^{\text {th }}$ Int. Symp. On digestive physiology in pigs. Wageningen. The Netherlands. 5:401-403.

Jadhav, N. V. and Siddiqui M. F. 2007. Handbook of poultry production and management $2^{\text {nd }}$ edition. Jaypee borthers medical publishers $(P)$ Ltd, 164-168.

McDonald, P., Edwards, K. A. and Greengangh, J. F. D. 1995. Animal nutrition, $5^{\text {th }}$ ed. Published by Oliver and Boyd, 234:137-234.

Marsman, G. J. H., Gruppen, A. F., Van, Der Poel. R. P., Kwakkel, M., Verstegen, W. and Voragen, G. 1997. The effect of thermal processing and enzyme treatments of soybean meal on growth performance, Illeal Nutrient Digestibility and Chyme characteristics in broiler chicks. Poultrysci. 76:864-872.

McCleary, B. V. 2001. Analysis of feed enzymes. In: enzymes in farm animal nutrition (Bedford, M.R. and partridge, G.G. Eds), CABI, Wallingford 85-108.

McGinnis, J. 1980. Influence of enzyme supplementation of nutrient value of different grains J. Poult. Sci. 37:372-375.

Morley, A. J. 2007. Successful poultry management biotech Books. 239244. 
National Research Council 1994. Nutrient requirement of poultry. $9^{\text {th }}$ Revised Edition, National Academy Press, Washington, $D C$.

Naveed, A. 1999. The effect of enzyme supplementation of UL grown lupin seeds on growth and nutrient digestibility in broilers. MSc thesis, University of Aberdeen.

Newman, K. 1991. Phytase: the enzyme, its origin and characteristics, impact and potential for increasing phosphorous availability: In T.P. Lyons (Editors). Biochemistry in the feed industry; proc. Altech's $7^{\text {th }}$ annual symp. Altech Technical publications, Nicholasrille, Ky169-177.

Obioha, F. C. 1992. A guide to poultry production in the tropics. Acena Publ. Enugu.

Odetallah, N. H. 2000. The use of dietary enzymes to alleviate enteric disorders of turkeys. PhD thesis, North Carolina State University.

Ohiwofa, K. 2001. Alternative energy sources in poultry feed production. The role of enzymes. Workshop of Poult. Association of Nigeria. Lagos $26^{\text {th }}$ July, 2001.

Olomu, J. M. 1995. Monogastric animal nutrition principles and practice. Jachem publications, Benin city, Nigeria.

Oluyemi, J. A. and Robert, F. A. 2000. Poultry production in warm wet climate. $2^{n d}$ ed. Macmillan press Ltd. London.

Onifale, A. A. 1997. Comparative response of broiler chicks to high fibre diet supplementation with four antibiotics. ANM FEED SCI. Techno 64:332-342.

Onunkwo, D. N., Anyaegbu, B. C., Ezike, J. C and Daniel-Igwe, G 2019. Dietary substitution of soya bean meal with processed African yam bean meal as protein source in the diets of finisher broilers. Nigerian Journal of Animal Production, 46(2):118-127.

Onwudike, O. C. 1983. Tropical animal production. Department of animal science, university of Ife, Ile-Ife, Nigeria. 39-44.

Ray, V. Herson 1994. The science of animal agriculture, Delmar publishers Inc. 71-72.

Savory, C. J. 1992. Enzyme supplementation, degradation and metabolism of three $\mathrm{U}^{14} \mathrm{C}$-labeled cell wall substrates in the fowl. Brit. J. Nutr. 67:91-102.

Schaible, C. J. 1992. Anatomy and physiology. Pp. 71-90. Inc; poultry feeds and nutrition. P.J. Schaible, ed. The Avi publishing company Inc. Westport. Connecticut.

Scott, A.J. 1973. Poultry feeding and management in the tropics. Proceedings of the international symposium on animal production in the tropics, Ibadan Nigeria, March 1973.

Shirly, R. B. and Edwards, H. M. 2003. Graded levels of phytase past industry standards improves broiler performance. Poult. Sci. 82:670680.

Simons, P.C.M., Newman, K. 1991. Improvement of phosphorous availability by microbial phytase in broilers and pigs. Brit. J. Nutri. 64:525-540.

Stephen, W. D. 2006. Introduction to animal sci. $3^{\text {rd }}$ Ed. Published by Calisle communications Ltd. 198100.

Thomas, G. F. and Robert, E. T. 2008. Scientific farm animal productions. An introduction to animal science. $9^{\text {th }}$ ed. Carlisle publishing services. 288-290.

Whitehead, C. C. 2002. Nutrition and 
poultry welfare. World's poultry science journal. 58(4): 349-355.

Wilson, G. 2005. Encyclopedia of animal science. MarclDekkers USA. 704707.

Wilson, G. Pond 2006. Basic animal nutrition of feeding. Fifth ed. John Wiley and Sons publishers Inc. 121-122.

Wisema, J. 1992. The use of exogenous enzymes in relation to nutrition and pollution. Proc. of the world's poultry congress. Amsterdan. The Netherlands 223-226.

Wuntner, A. M. 1995. Influence of liquid feed enzymes on performance and nutrient retention of broiler chickens fed a cereal diet. In: $2^{\text {nd }}$ European symp. On feed enzymes, Noordwijkerhout, 293-296.
Wyatt, C. L., Bedford, M. R. and Waldon, L. A. 1999. Role of enzymes in reducing variability, nutritive value of maize using the lical digestibility method. In: proceedings of Aust. Poult. Sci. symp. 10 sydney, Austia, 108-111.

Yousefpour, Mohammadreza 2001. Investigation of the effect of multienzyme performance. Islamic Azad University, Karai.

Zyla, K., Gogal, D., Koreleski, J., Swiatkiewiez, S. and Ledoux, D.R. 1999. Simultaneous application of phytase and xylase to broilers. J.Sci. Food and Agric. 79:1841-1850.

Received: $1^{\text {st }}$ October, 2019

Accepted: $17^{\text {th }}$ January, 2020 